\title{
Melanogenesis Inhibitory and Free Radical Scavenging Activities of Diarylheptanoids and Other Phenolic Compounds from the Bark of Acer nikoense
}

\author{
Hiroyuki Akazawa, ${ }^{a}$ Toshihiro Akinisa, ${ }^{*}, a$ Yosuke Taguchi, ${ }^{a}$ Norihiro Banno, ${ }^{b}$ Risa Yoneima, ${ }^{a}$ and \\ Ken YASUKAWA ${ }^{c}$ \\ ${ }^{a}$ College of Science and Technology, Nihon University; 1-8 Kanda Surugadai, Chiyoda-ku, Tokyo 101-8308, Japan: \\ ${ }^{b}$ Ichimaru Pharcos Company Ltd.; 318-1 Asagi, Motosu, Gifu 501-0475, Japan: and ${ }^{c}$ College of Pharmacy, Nihon \\ University; 7-7-1 Narashinodai, Funabashi, Chiba 274-8555, Japan. Received March 6, 2006; accepted June 28, 2006
}

\begin{abstract}
Melanogenesis inhibitory and free radical scavenging activities of nine cyclic $(1-9)$ and one acyclic diarylheptanoids (10), and two phenolic compounds, (+)-rhododendrol (11) and (+)-catechin (12), isolated from the ethyl acetate-soluble fraction of the MeOH extract of the bark of Acer nikoense MAXIM. (Aceraceae) were examined. Upon evaluation of compounds 1-12 on the melanogenesis in the B16 melanoma cells, two compounds, 2 and 8 , exhibited marked inhibitory activity with $55.6 \%$ and $46.8 \%$ reduction, respectively, of melanin content at $25 \mu \mathrm{g} / \mathrm{ml}$ without inhibition of cell proliferation. In addition, upon an evaluation of eleven compounds, $1-7$ and 9-12 against the scavenging activities of free radicals (against the 1,1-diphenyl-2-picrylhydrazyl (DPPH) radical), compound $12\left(\mathrm{IC}_{50} 9.0 \mu \mathrm{M}\right)$ followed by compounds $1,3,4$, and $6\left(\mathrm{IC}_{50} 40.2-44.0 \mu \mathrm{M}\right)$ showed potent scavenging activities.
\end{abstract}

Key words Acer nikoense; diarylheptanoid; melanogenesis; antioxidant activity; radical scavenging

The bark from the Japanese maple tree, Acer nikoense MaXIm. (Aceraceae) (Japanese name, Megusurino-ki) has been used as a folk medicine for the treatment of hepatic disorders and eye disease. ${ }^{1)}$ The bark has been reported to contain various diarylheptanoid and phenolic compounds ${ }^{2-4)}$ possessing several biological properties ${ }^{5,6)}$ including hepatoprotective effects. ${ }^{7)}$ In the course of our studies on the bioactive principles from natural sources, we have evaluated recently the diarylheptanoid and phenolic constituents of the extract of $A$. nikoense stem bark for their inhibitory effects on 12-O-tetradecanoylphorbol-13-acetate (TPA)-induced inflammation in mice, and on Epstein-Barr virus early antigen (EBV-EA) activation induced by TPA. ${ }^{8)}$ In this paper, we describe the inhibitory effects against melanogenesis in the B16 melanoma cells and free radical scavenging activities on 1,1-diphenyl-2-picrylhydrazyl (DPPH) radical of the extracts and their diarylheptanoid and phenolic constituents of $A$. nikoense bark.

\section{MATERIALS AND METHODS}

Instruments Silica gel and $\mathrm{C}_{18}$ silica (Chromatorex-
ODS; Fuji Silysia Chemical Ltd., Aichi, Japan) were used for open column chromatography. Reversed-phase preparative HPLC was carried out on a $\mathrm{C}_{18}$ silica column $(25 \mathrm{~cm} \times 10 \mathrm{~mm}$ i.d.; flow rate of the mobile phase: $3.0 \mathrm{ml} / \mathrm{min}$ ) at $25^{\circ} \mathrm{C}$.

Materials and Chemicals The stem bark obtained from a 25 year old tree of Acer nikoense in the summer of 2002 was purchased from Sirakami Fruit Park (Gunma, Japan). ${ }^{8)}$ Fetal bovine serum (FBS) was purchased from Trace Scientific LTD (Melbourne, Australia). Eagle's minimal essential medium (MEM) was obtained from Gibco (Grand Island, NY, U.S.A.). 1,1-Diphenyl-2-picrylhydrazyl (DPPH), arbutin (4-hydroxyphenyl $\beta$-D-glucopyranoside), and DL- $\alpha$-tocopherol were purchased from Tokyo Kasei Kogyo Co., Ltd. (Tokyo, Japan).

Extraction and Isolation Extraction of the bark of $A$. nikoense, and isolation and identification of ten diarylheptanoids, 1-10, and two phenolic compounds, 11 and 12, were described in our recent paper. ${ }^{8)}$ The dried stem bark of A. nikoense $(450 \mathrm{~g})$ was finely cut and extracted three times with $n$-hexane under reflux for $3 \mathrm{~h}$ which yielded the extract $(3.4 \mathrm{~g})$. The residue was then extracted three times with $\mathrm{MeOH}$ under reflux for $3 \mathrm{~h}$ giving the extract $(63.6 \mathrm{~g})$ which

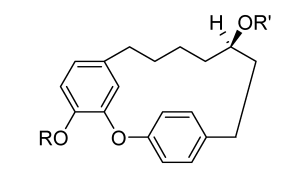

$1 \mathrm{R}=\mathrm{R}^{\prime}=\mathrm{H}$ $2 \mathrm{R}=\mathrm{Glc}, \mathrm{R}^{\prime}=\mathrm{H}$ $3 \mathrm{R}=\mathrm{H}, \mathrm{R}^{\prime}=\mathrm{Glc}-(6 \rightarrow 1)-\mathrm{Api}$

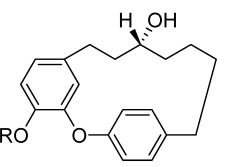

$4 \mathrm{R}=\mathrm{H}$ $5 \mathrm{R}=\mathrm{GlC}$

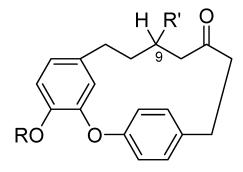

$6 \mathrm{R}=\mathrm{H}, \mathrm{R}^{\prime}=\mathrm{OH}$ $7 \mathrm{R}=\mathrm{Glc}, \mathrm{R}^{\prime}=\mathrm{H}$

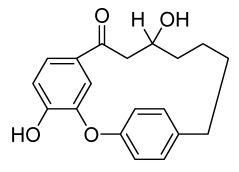

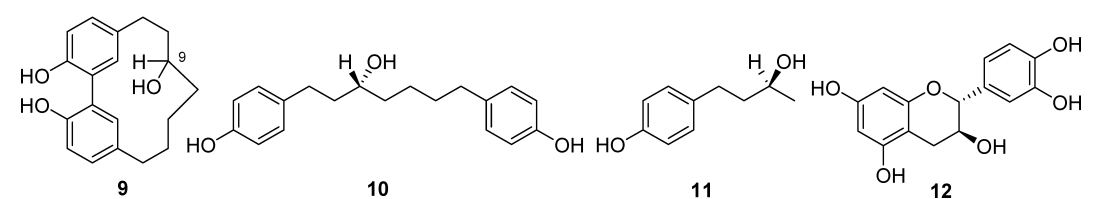

Chart 1. Structures of Compounds $\mathbf{1}-\mathbf{1 2}$ 
was partitioned in an EtOAc- $\mathrm{H}_{2} \mathrm{O}(1: 1, \mathrm{v} / \mathrm{v})$ mixture. The aqueous layer was extracted with $n$-butanol $(n-\mathrm{BuOH})$, and removal of the solvent from the EtOAc-, $n-\mathrm{BuOH}-$, and $\mathrm{H}_{2} \mathrm{O}-$ soluble portions yielded $26.2,26.6$, and $4.5 \mathrm{~g}$ of the residue, respectively.

Column chromatography on silica gel $(800 \mathrm{~g})$ of the EtOAc-soluble fraction $(25.2 \mathrm{~g})$ eluted with $n$-hexane-EtOAc $(1: 0 \rightarrow 0: 1)$ and then with EtOAc-MeOH $(7: 3 \rightarrow 0: 1)$ gave five fractions, fractions $1-5$. Fraction $3(1.98 \mathrm{~g})$ was further separated by column chromatography on silica gel (100 g) [ $n$-hexane-EtOAc $(2: 3 \rightarrow 0: 1)$ and then EtOAc-MeOH $(95: 5 \rightarrow 0: 1)]$ to furnish six fractions, fractions 3-1-3-6. Preparative HPLC $\left[\mathrm{MeOH}-\mathrm{H}_{2} \mathrm{O}\right.$-acetic acid $(\mathrm{AcOH})$ $(65: 35: 0.1, \mathrm{v} / \mathrm{v} / \mathrm{v})]$ of fraction $3-1(140 \mathrm{mg})$ gave acerogenin A (1), $(R)$-acerogenin B (4), and (-)-centrolobol (10). In addition, preparative HPLC of fraction 3-2 (416 mg) under the same condition as above yielded compounds $\mathbf{1}, \mathbf{4}$, acerogenin $\mathrm{D}(\mathbf{6})(\mathrm{C}-9 \xi),{ }^{3)}$ acerogenin $\mathrm{M}(\mathbf{8})(\mathrm{C}-9 \xi),{ }^{8)}$ acerogenin $\mathrm{K}(\mathbf{9})$ $(\mathrm{C}-9 R / S$ mixture $),{ }^{4)}$ and 10, along with a highly polar fraction. The latter fraction was further subjected to HPLC $\left[\mathrm{MeOH}-\mathrm{H}_{2} \mathrm{O}-\mathrm{AcOH}(50: 50: 0.1, \mathrm{v} / \mathrm{v} / \mathrm{v})\right]$ which afforded (+)-rhododendrol (11). Chromatography of fraction 4 $(528 \mathrm{mg})$ on ODS column $(45 \mathrm{~g})\left[\mathrm{MeOH}-\mathrm{H}_{2} \mathrm{O}(1: 4 \rightarrow 1: 0)\right]$ gave four fractions, fractions 4-1-4-4. Upon HPLC [acetonitrile $\left.(\mathrm{MeCN})-\mathrm{H}_{2} \mathrm{O}(13: 7, \mathrm{v} / \mathrm{v})\right]$, fraction $4-2(150 \mathrm{mg})$ afforded $(+)$-catechin (12). Fraction 5 (20.53 g) was subjected to further chromatography on silica gel $(800 \mathrm{~g})$ [EtOAc-MeOH $(4: 1 \rightarrow 0: 1)]$ which yielded five fractions, fractions 5-1-5-5. Fraction 5-1 (141 mg) was subjected to HPLC [MeOH- $\left.\mathrm{H}_{2} \mathrm{O}(11: 9, \mathrm{v} / \mathrm{v})\right]$ to give aceroside IV (7). Chromatography of fraction $5-2(452 \mathrm{mg})$ on ODS column $(35 \mathrm{~g})\left[\mathrm{MeOH}-\mathrm{H}_{2} \mathrm{O}(1: 1 \rightarrow 1: 0)\right]$ gave four fractions, fractions $5-2 \mathrm{a}-5-2 \mathrm{~d}$. Further HPLC $\left[\mathrm{MeCN}-\mathrm{H}_{2} \mathrm{O}(3: 7, \mathrm{v} / \mathrm{v})\right]$ was performed on fraction $5-2 b(27 \mathrm{mg})$ which yielded aceroside I (2); fraction 5-2c (145 mg) afforded 2, aceroside III (3), and aceroside $B_{1}(5)$; and fraction $5-2 \mathrm{~d}(210 \mathrm{mg})$ gave 3. Percent compositions of individual compounds in the EtOAc-soluble fraction was estimated based on the weight of isolated compounds as: 1 (ca. 0.01\%), 2 (0.5\%), 3 (3.3\%), 4 (10.5\%), $5(0.8 \%), 6(1.2 \%), 7(0.02 \%), 8(0.6 \%), 9(0.02 \%)$, $10(0.1 \%), 11(0.4 \%)$, and $12(0.4 \%)$ (refer to Chart 1 for the chemical structures).

Cell Culture B16 murine melanoma cells purchased from Riken Cell Bank (Tsukuba, Japan) were cultured in MEM supplemented with 5\% FBS, 100 units/ml penicillin, and $100 \mu \mathrm{g} / \mathrm{ml}$ streptomycin at $37^{\circ} \mathrm{C}$ in a humidified $\mathrm{CO}_{2}$ controlled (5\%) incubator.

Determination of Cell Proliferation Using the 3-(4,5dimethyl-2-thiazolyl)-2,5-diphenyl- $\mathrm{H}$-tetrazolium bromide (MTT) based colorimetric assay assessed cell proliferation. After $72 \mathrm{~h}$ incubation with test compounds, MTT $(100 \mu \mathrm{l}$, $5 \mathrm{mg} / \mathrm{ml}$ in phosphate-buffered saline) solution was added to the wells. After $3 \mathrm{~h}$ of incubation, the medium was removed, and 2-propanol containing $0.04 \mathrm{M} \mathrm{HCl}$ was added to dissolve the formazan produced in the cells. The absorbance of each well was then read at $570 \mathrm{~nm}$ (reference, $620 \mathrm{~nm}$ ) by using ELISA Microplate Reader (Labsystem Multiskan MS-UV). The optical density of formazan formed by control cells was used as a reference (assumed to be $100 \%$ ).

Assay of Melanin Content Test samples dissolved in dimethylsulfoxide (DMSO) were added to the cell culture at final concentration of $25 \mu \mathrm{g} / \mathrm{ml}$. B16 cells, plated at $2 \times 10^{5}$ cells in a culture dish $(60 \mathrm{~mm} \phi)$, were pre-incubated for $24 \mathrm{~h}$ After then, the medium was transferred into $5 \mathrm{ml}$ of fresh medium containing the test sample and cultured for $3 \mathrm{~d}$. The cells were harvested by trypsinization. The samples were dissolved in $1 \mathrm{ml}$ of $1 \mathrm{M} \mathrm{NaOH}$ containing $10 \% \mathrm{DMSO}$, and the amount of melanin was determined spectrophotometrically by absorbance at $420 \mathrm{~nm}$ using the ELISA Microplate Reader. The optical density of control cells was assumed to be $100 \%$.

Radical Scavenging Assay The radical scavenging activity of a sample was determined by the DPPH method (slight modification of Terasawa and Yamazaki's method). ${ }^{9}$ A sample was dissolved in a DMSO, and then $10 \mu \mathrm{l}$ of this solution, $200 \mu \mathrm{l}$ of $\mathrm{EtOH}, 200 \mu \mathrm{l}$ of $0.1 \mathrm{~m}$ acetate buffer $(\mathrm{pH}$ 5.5), and $100 \mu \mathrm{l}$ of $500 \mu \mathrm{M} \mathrm{DPPH} / \mathrm{EtOH}$ were mixed in a test tube. A control was made up with DMSO added instead of the sample solution. The absorbance at $530 \mathrm{~nm}$ of the solution was measured $30 \mathrm{~min}$ after mixing at room temperature. The radical scavenging activity was calculated using the following equation: \% scavenging activity $=\left[A_{\text {control }}-A_{\text {sample }}\right] /$ $A_{\text {control }} \times 100$. Each sample was measured in triplicate. The $50 \%$ inhibitory concentration $\left(\mathrm{IC}_{50}\right.$; concentration of sample required to scavenge $50 \%$ of DPPH radicals) values were determined by the method of probit-graphic interpolation for six concentration levels.

\section{RESULTS AND DISCUSSION}

The melanin content was reduced to $34.6 \%$ and $62.9 \%$ by addition of the $n$-hexane and $\mathrm{MeOH}$ extracts $(25 \mu \mathrm{g} / \mathrm{ml})$, respectively, to an incubation medium of the B16 melanoma cell. The $n$-hexane extract inhibited cell proliferation at that concentration whereas the $\mathrm{MeOH}$ extract promoted it slightly. The $\mathrm{MeOH}$ extract was then fractionated into EtOAc-, $n$-BuOH-, and $\mathrm{H}_{2} \mathrm{O}$-soluble fractions. As compared to the other fractions, the EtOAc-soluble fraction suppressed most significantly the melanin content $(58.0 \%$ of melanin content at $25 \mu \mathrm{g} / \mathrm{ml}$ ) (Table 1). From this fraction we isolated ten diarylheptanoids, $\mathbf{1}-\mathbf{1 0}$, and two phenolic compounds, 11 and 12. Six compounds, 1, 4, 6, and 9-11, strongly inhibited melanogenesis in melanoma cell with the melanin content of $7.8-26.1 \%$ at $25 \mu \mathrm{g} / \mathrm{ml}$. Most of the inhibitory activity of these compounds is thought to be due to their cytotoxic action since they reduced significantly cell viability (to $19.2-57.9 \%$ of cell viability at $25 \mu \mathrm{g} / \mathrm{ml}$ ). Two compounds, $\mathbf{2}$ and $\mathbf{8}$, showed remarkable inhibition of melanogenesis (melanin content $44.4 \%$ and $53.2 \%$, respectively, at $25 \mu \mathrm{g} / \mathrm{ml}$ ) with no toxicity to the cells because cell viabilities were $100.1 \%$ and $108.0 \%$, respectively.

The $\mathrm{MeOH}$ extract of the bark of A. nikoense, and the EtOAc-, $n$-BuOH-, and $\mathrm{H}_{2} \mathrm{O}$-soluble fractions obtained from the $\mathrm{MeOH}$ extract exhibited strong antioxidant activity with $\mathrm{IC}_{50}$ values of $1.9-5.0 \mu \mathrm{g} / \mathrm{ml}$, whereas the $n$-hexane extract showed weak activity $\left(\mathrm{IC}_{50} 95.5 \mu \mathrm{g} / \mathrm{ml}\right.$ ) (Table 1 ), on DPPH radical-scavenging assay. This assay has been widely used to measure the radical-scavenging ability of various plant extracts and constituents. ${ }^{9-11)}$ On evaluation of the DPPH radical-scavenging activity of nine diarylheptanoids, $\mathbf{1}-\mathbf{7}, \mathbf{9}$, and 10, and two phenolics, 11 and 12, isolated from the EtOAc-soluble fraction, four diphenyl ether-type cyclic di- 
Table 1. Melanogenesis Inhibitory Activities and Cytotoxicities in B16 Mouse Melanoma Cells, and DPPH Free Radical Scavenging Activities of the Extracts of Acer nikoense Stem Barks and the Compounds Isolated from the Extracts

\begin{tabular}{|c|c|c|c|c|}
\hline \multirow{3}{*}{ Extract and compound } & \multicolumn{2}{|c|}{ Melanogenesis inhibitory activity and cytotoxicity } & \multicolumn{2}{|c|}{ DPPH free radical scavenging activity } \\
\hline & \multicolumn{2}{|c|}{ Mean \pm S.E. $(\%)^{a)}$} & \multicolumn{2}{|c|}{$\mathrm{IC}_{50}{ }^{c)}$} \\
\hline & Melanin content $t^{b)}$ & Cell viability $^{b)}$ & $\mu \mathrm{g} / \mathrm{ml}$ & $\mu \mathrm{M}$ \\
\hline Control (100\% DMSO) & $100.0 \pm 1.35$ & $100.0 \pm 2.50$ & & \\
\hline$n$-Hexane extract & $34.6 \pm 1.80^{d)}$ & $86.6 \pm 1.57^{e)}$ & 95.5 & \\
\hline $\mathrm{MeOH}$ extract & $62.9 \pm 1.86^{d)}$ & $115.4 \pm 1.82^{d)}$ & 1.9 & \\
\hline EtOAc-soluble fraction & $58.0 \pm 2.60^{d)}$ & $112.8 \pm 0.99^{d)}$ & 4.1 & \\
\hline$n$-BuOH-soluble fraction & $79.5 \pm 1.57^{e)}$ & $121.6 \pm 0.68^{d)}$ & 2.4 & \\
\hline $\mathrm{H}_{2} \mathrm{O}$-soluble fraction & $94.4 \pm 2.59$ & $113.3 \pm 0.78^{d)}$ & 5.0 & \\
\hline 1 Acerogenin A & $7.8 \pm 0.19^{d)}$ & $43.6 \pm 2.15^{d)}$ & & 40.2 \\
\hline 2 Aceroside I & $44.4 \pm 1.04^{e)}$ & $100.1 \pm 1.05$ & & $>200$ \\
\hline 3 Aceroside III & $78.9 \pm 5.04$ & $93.3 \pm 1.39^{d)}$ & & 44.0 \\
\hline $4(R)$-Acerogenin B & $8.2 \pm 0.42^{d)}$ & $36.0 \pm 1.03^{d)}$ & & 40.2 \\
\hline 5 Aceroside $\mathrm{B}_{1}$ & $28.1 \pm 3.87^{e)}$ & $87.6 \pm 1.53^{d)}$ & & $>200$ \\
\hline 6 Acerogenin D & $26.1 \pm 0.59^{d)}$ & $57.9 \pm 2.29^{d)}$ & & 40.4 \\
\hline 7 Aceroside IV & $68.9 \pm 8.21$ & $94.7 \pm 1.08^{d)}$ & & $>200$ \\
\hline 8 Acerogenin $\mathrm{M}$ & $53.2 \pm 2.57^{e)}$ & $108.0 \pm 0.80^{d)}$ & & \\
\hline 9 Acerogenin $\mathrm{K}$ & $10.0 \pm 0.51^{d)}$ & $29.6 \pm 2.04^{d)}$ & & $>200$ \\
\hline $\mathbf{1 0}(-)$-Centrolobol & $8.0 \pm 0.72^{d)}$ & $19.2 \pm 0.59^{d)}$ & & $>200$ \\
\hline $11(+)$-Rhododendrol & $23.4 \pm 1.43^{d)}$ & $47.6 \pm 1.29^{d)}$ & & $>200$ \\
\hline $12(+)$-Catechin & $88.3 \pm 3.11$ & $108.3 \pm 2.67^{d)}$ & & 9.0 \\
\hline \multicolumn{5}{|l|}{ Reference compound } \\
\hline Arbutin & $76.4 \pm 3.58$ & $102.3 \pm 0.81$ & & \\
\hline$\alpha$-Tocopherol & & & & 27.1 \\
\hline
\end{tabular}

a) Sample concentration determined was $25 \mu \mathrm{g} / \mathrm{ml}$ except for compound 7 which was determined at $12.5 \mu \mathrm{g} / \mathrm{ml}$. Melanin contents (\%) and cell viability ( $\%$ ) were determined based on the absorbances at 420 and $570 \mathrm{~nm}$, respectively, by comparison with those for DMSO (100\%). The absorbances at 420 and 570 nm of DMSO were 0.452 and 0.344 , respectively. b) Values of fourfold experiments. Concentration of DMSO in the sample solution was $5 \mu 1 / \mathrm{ml}$. c) Each sample was measured in triplicate. Concentration of DMSO in the sample solution was $20 \mu \mathrm{l} / \mathrm{ml}$. The $50 \%$ inhibitory concentration $\left(\mathrm{IC}_{50}\right)$ values were determined by the method of probit-graphic interpolation for six concentration levels. d) $p<0.001$ by Student's $t$-test compared with the control group. e) $p<0.01$ by Student's $t$-test compared with the control group.

arylheptanoids, 1, 3, 4, and 6, exhibited potent radical-scavenging activities with $\mathrm{IC}_{50}$ values of 40.2, 44.0, 40.2, and $40.4 \mu \mathrm{M}$, respectively, which being almost comparable with that of a known antioxidant, $\alpha$-tocopherol ( $\left.\mathrm{IC}_{50} 27.1 \mu \mathrm{M}\right)$. Based on the radical-scavenging activities of compounds 2 $\left(\mathrm{IC}_{50}>200 \mu \mathrm{M}\right), 3(44.0 \mu \mathrm{M}), \mathbf{5}(>200 \mu \mathrm{M}), \mathbf{6}(40.4 \mu \mathrm{M})$, and $7(>200 \mu \mathrm{M})$, it can be deduced that glycosylation at the phenolic hydroxyl group (compounds $\mathbf{2}, \mathbf{5}, \mathbf{7}$ ) reduced significantly the activity, whereas that at the heptyl-chain hydroxyl group (compound 3) exerted almost no influence on the activity of the diarylheptanoids. This suggests that radicalscavenging activity of the diphenyl ether-type cyclic diarylheptanoids is highly associated with the presence of a free phenolic hydroxyl group. Compound $\mathbf{1 2}$ exhibited the most strong radical-scavenging activity $\left(\mathrm{IC}_{50} 9.0 \mu \mathrm{M}\right)$ among the others tested in this study, and such a high activity of $\mathbf{1 2}$ is consistent with that reported recently. ${ }^{11-13)}$

Our data indicate that the extracts and some of the diarylheptanoid and phenolic constituents of $A$. nikoense tree bark are useful as skin whitening agents as well as natural antioxidants. Constituents of the $n$-hexane extract, and the $n$-BuOHand $\mathrm{H}_{2} \mathrm{O}$-soluble fractions from the $\mathrm{MeOH}$ extract from the bark of $A$. nikoense are now being investigated.

Acknowledgments The authors thank Dr. W. C. M. C. Kokke (Ardmore, PA), for reviewing the manuscript. The authors are also indebted to Mr. M. Ukiya (College of Science and Technology, Nihon University) for his technical assistance.

\section{REFERENCES}

1) Izawa K., "Colored Picture Book of Medicinal Herb,” Vol. 2, Shufunotomo Co., Ltd., Tokyo, 1991, pp. 195-196

2) Inoue T., Yakugaku Zasshi, 113, 181-197 (1993).

3) Nagumo S., Kaji N., Inoue T., Nagai M., Chem. Pharm. Bull., 41, 1255-1257 (1993).

4) Nagumo S., Ishizawa S., Nagai M., Inoue T., Chem. Pharm. Bull., 44, 1086-1089 (1996).

5) Morikawa T., Tao J., Ueda K., Matsuda H., Yoshikawa M., Chem. Pharm. Bull., 51, 62-67 (2003).

6) Morikawa T., Tao J., Toguchida I., Matsuda H., Yoshikawa M., J. Nat. Prod., 66, 86-91 (2003).

7) Shinoda M., Ohta S., Kumasaka M., Fujita M., Nagai M., Inoue T., Shoyakugaku Zasshi, 40, 177-181 (1986).

8) Akihisa T., Taguchi Y., Yasukawa K., Tokuda H., Akazawa H., Suzuki T., Kimura Y., Chem. Pharm. Bull., 54, 735-739 (2006).

9) Terasawa N., Yamazaki N., Food Sci. Technol. Res., 8, 218-220 (2002).

10) Hou W.-C., Lin R.-D., Chen K.-T., Hung Y.-T., Cho C.-H., Chen C.-H., Hwang S.-Y., Lee M.-H., Phytomedicine, 10, 170-175 (2003).

11) Cho E. J., Yokozawa T., Rhyu D. Y., Kim S. C., Shibahara N., Park J. C., Phytomedicine, 10, 544-551 (2003).

12) Kishi A., Morikawa T., Matsuda H., Yoshikawa M., Chem. Pharm. Bull., 51, 1051-1055 (2003).

13) Cai Y., Sun M., Corke H., J. Agric. Food Chem., 51, 2288-2294 (2003). 